\title{
THE JOYS AND TRIALS OF A NATURALIST
}

DONALD F. HOOPER, Box 40, Somme, Saskatchewan. SOE 1NO

\section{Joys}

I am absolutely overwhelmed with the five awards that have been presented to me since October of 1991 in recognition of my work in natural history and conservation. The real thriller for me is to add something new to the Saskatchewan list. It seems that instilled in the mind of every naturalist is a mania (an excessive/persistent enthusiasm) to explore and find the unknown in the great outdoors.

Some of my firsts are as follows:

1955 - Mexican Sulphur (Erema mexicana) (a stray tropical butterfly);

1958 - a ground beetle (Bembidion lanciphoroides); and

1990 - first Nashville Warbler nest for Saskatchewan.

With Dr. Vern Harms, Les Baker of Carragana and others, I have shared in finding 10 new plant species for the province.

\section{Trials}

Worried Neighbours When I take a summer day to head for the woods some of my neighbours are concerned about my farm work. To be a naturalist is often to be grossly misunderstood. Many say that one should be paid by the government for time and expenses. It is odd that they don't stop to think of all the money that they spend in a year on leisure (sports, hunting, and trips to Disneyland, etc.).

Grounded by an Owl In 1956 I was climbing up a large aspen tree to band and photograph a young owl in the nest. When I got about $4 \mathrm{~m}$ up, without warning, the adult owl on silent wings descended upon me, striking me like a sledge hammer on the back of my head with the soles of its feet. The bird clawed through the top and bottom eyelids of my right eye as it flew past. Needless to say I dropped to the ground stunned. I was not going to give up, so the next day I climbed the tree with a cardboard box over my head and safely completed my assignment.

\section{My Camera Goes Under Water} Around 1960 I set up my camera on a tripod along the edge of a mucky cattail slough. I intended to trip the camera shutter with an air bulb and a long hose when a bird came into proper position for a picture, but suddenly the tripod started tipping sideways in the muck. I ran to rescue my camera, but to my dismay it settled with a splash into the water. The camera had to be sent to Vancouver for cleaning and repairs.

Suspected of Rustling While travelling in Alberta in 1970 I stopped along a road allowance beside a community pasture. It was a nice prairie meadow with a beautiful array of flowers. I got out my net and proceeded to check for butterflies. After a while a squad car pulled up on the highway; the officer came over and 
the approach of the Greenbush campsite. Leaving the parking lights on, I took a flashlight and found that I had another Red-backed Mouse in one of the traps. I muttered as I gathered up the traps and the mouse. "What is this mouse doing in so wet a place?" I wondered.

While I was walking through the wet bog toward the truck a police squad car pulled up on the highway. I thought to myself, "He will never believe me." The season was open for deer hunting north of Highway 3 , but not on the south side where I was. $\mathrm{He}$ would think that I was dragging out a deer. When I got to my vehicle I tossed the mouse and flashlight in and got the motor started and put the headlights on. With the red light flashing, the squad car pulled in behind me. I quickly got out of my truck and went back to where the policeman was. The officer opened his car door and remained sitting with his dome light on.

He asked, "What were you doing out there?"

I replied, "Trapping mice." He then looked me over. His eyes went from my head to my feet and then back again.
He said very slowly, "T-r-a-p-p-i-n-g mice?"

I answered enthusiastically, "I was hoping to catch a Northern Bog Lemming."

He again repeated slowly, "A n-o-r-t-h-e-r-n b-o-g l-e-m-m-i-n-g?" Then he added, "There are a lot of deer in these parts." (I guess he was suspicious of me poaching).

I explained to him that I was Donald Hooper, a naturalist from Somme, and did all kinds of unusual things in my nature studies. After telling some of my exploits I said, "You must have read about me in the Hudson Bay Post Review."

He then replied, "I never heard of you in my life."

So I said, "I'll show you the mouse if you like."

The officer said, "I think that I had better be going." He went off in the darkness toward Hudson Bay. I have often wondered if he ever told the boys at the station about the strange mouse trapper at Greenbush.

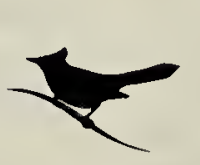

Ohio Senate Committee, 1857: "The passenger pigeon needs no protection. Wonderfully prolific, having the vast forests of the North as its breeding grounds, traveling hundreds of miles in search of food, it is here to-day and elsewhere to-morrow, and no ordinary destruction can lessen them or be missed from the myriads that are yearly produced." Peter Mattiessen. 1959. Wildlife in America. Viking, NY. (p. 158) 